\title{
An Analysis of the Verses in the Tattvārthādhigamabhāşya
}

\author{
Lucas den Boer \\ Leiden University, Leiden, The Netherlands \\ L.denBoer.1@gmail.com
}

\begin{abstract}
The Tattvārthädhigamabhāsya, which is an early commentary on the Tattvārthādhigama attributed to Umāsvāti, contains several passages in verse. The inclusion of these verses has not been studied before, even though they are relevant for the discussion of the relationship between the Tattvārthädhigama and the bhassya. This article provides an analysis and translation of these verses, including the introductory verses and the colophon that usually accompany this text. Although some scholars regard the bhāsya as an auto-commentary, the outcomes of this analysis indicate that the bhäsya was written by a different author. Further, this study shows that some of the verses in the bhassya are derived from other Jaina works in Sanskrit that are no longer extant. This suggests that the Tattvārthādhigama was not the only Jaina philosophical text in Sanskrit at the time of the final redaction of the bhāsya.
\end{abstract}

\section{Keywords}

Tattvārthādhigama - Tattvārthādhigamabhāṣya - sambandhakārikās - praśasti - Umāsvāti - Jaina philosophy

The Tattvārthädhigama ${ }^{1}$ (hereafter TA) is the oldest extant treatise on Jaina philosophy and has played a crucial role in the development of Jaina thought.

1 The Tattvārthādhigama is more commonly known as the Tattvārthasūtra or Tattvārthādhigamasūtra. I use the title Tattvārthädhigama, which is mentioned as the title of the text in the introductory verses and the colophon that accompany the bhäsya. See also my discussion of the sambandhakārikās and praśasti below. 
The TA was probably written in the 4th cent. CE and is usually attributed to Umāsvāti, ${ }^{2}$ who is mentioned as the author of the work in the colophon of the Tattvārthädhigamabhāsya (hereafter TABh). The identity of the author of the TABh and its colophon is, however, not clear. Writers in the Śvetāmbara tradition regard the text as an auto-commentary, a claim denied by most Digambara authors, who assume that Pūjyapāda's Sarvārthasiddhi was the first commentary on the TA. These opposing views are also represented in contemporary scholarship. ${ }^{3}$

In order to interpret and date the TA and the TABh, it is crucial to know whether the TABh is an auto-commentary. Since the TA is composed in a concise manner, many passages are hard to understand and open to various explanations. If the TABh is an auto-commentary, however, we can assume that the commentator correctly interprets the sütras. Yet, if the commentator was a different author, we cannot be sure that the commentary is always in line with the intended meaning of the sütra. Furthermore, if the text is not an autocommentary, it is possible that the TA significantly predates the TABh, which has some consequences for our understanding of the development of early Jaina philosophy.

Unfortunately, the evidence for the authorship of the TA and the TABh that has been discussed in previous studies is rather inconclusive. It seems, however, that these studies have overlooked one aspect that is certainly relevant for the discussion of the authorship of both texts. Although the TABh is composed in prose, the text contains some passages in verse that are introduced as citations. As I explain below, these short citations suggest that it is unlikely that the TABh is an auto-commentary.

This article provides an analysis of the verses in the TABh, including the introductory verses (sambandhakārikās, hereafter sam-k) and the colophon

2 Contemporary Digambara sources favour the name Umāsvāmi instead of Umāsvāti. The name Umāsvāmi(n) also appears in general scholarly studies. For example, Piotr Balcerowicz attributes the TA to Umāsvāmin and the bhāssya to Umāsvāti (Balcerowicz 20o8: 35, n. 23). R. Williams makes a similar distinction between Umāsvāmin, the author of the TA, and Umāsvāti, the author of the Śrāvakaprajñapti (Williams 1963: 3, n. 4). Some southern manuscripts of the TA mention the variant name Umāsvāmi. However, this seems to be a late development that starts with Śrutasāgara's Tattvārthavrtti, which was written in the 15th or 16th cent. CE (Dhaky 1996: 54). Since the name Umāsvāmi(n) only appears after the 15 th cent. $\mathrm{CE}$, it is quite unlikely that this was the name of the composer of the TA or the bhāsya.

3 Suzuko Ohira (Ohira 1982) and M.A. Dhaky (Dhaky 1996), for example, argue that the TABh is an auto-commentary. By contrast, Johannes Bronkhorst (Bronkhorst 1985, 2010) and Piotr Balcerowicz (Balcerowicz 2008) assume that the author of the TA did not write the TABh. 
(praśasti). ${ }^{4}$ The first part of the article discusses the different verses in the TABh that are introduced as quotations. The second part deals with other passages in the TABh that are composed in verse but not introduced as quotations. In the third and fourth part, I provide an analysis of the introductory verses and the colophon that accompany the bhäsya. Although the authorship and date of these two short compositions are contested, I analyse whether these parts can be linked to the verses in the bhāsya itself. In addition, I discuss what the sam-k and praśasti can tell us about the authorship of the TA and the TABh.

The TABh contains three passages introduced with the expressions äha ca and uktam ca, which deviate from the main text. The first instance can be found at the end of the first chapter of the TABh, in a passage that summarises the Jaina theory of perspectives (nayavāda):

\begin{tabular}{|c|c|}
\hline [1.35.42] & naigamaśabdārthānām ekānekārthanayagamāpekșah | \\
\hline [1.35.43] & deśasamagragrāhī vyavahārī naigamo jñeyah $\|1\|$ \\
\hline$[1.35 \cdot 44]$ & yat sañgrhītavacanam sāmānye deśato 'tha ca viśeșe | \\
\hline $1.35 \cdot 45]$ & tat saìgrahanayaniyatam jñānam vidyān nayavidhijñah $\|2\|$ \\
\hline 1.35 .46$]$ & samudāyaryaktyākṛtisattāsaṃjñādiniścayāpekșam | \\
\hline 1.35.47] & lokopacāraniyataṃ vyavahāram vistrtam vidyāt $\left\|_{3}\right\|$ \\
\hline 5.48$]$ & sāmpratavișayagrāhakam ṛjusūtranayam samāsato vidyāt | \\
\hline 35.49] & $\begin{array}{l}\text { vidyād yathārthaśabdam viśeșitapadam tu śabdanayam }\|4\| \\
\text { iti } \|^{5}\end{array}$ \\
\hline
\end{tabular}

4 This article provides the first English translation of the sam- $k$ and the verses in the TABh, with the exception of the verses that conclude the tenth chapter. These verses and the praśasti have been translated before by Robert Zydenbos (Zydenbos 1983). Unless otherwise mentioned, all translations here are mine.

5 The transliteration of the Sanskrit text is primarily based on the edition of the TA and TABh by K.P. Mody (Mody 1903). I have also consulted the edition by Hiralal Rasikdas Kapadia (Kapadia 1926, 1930). In a number of cases, I have followed Kapadia's instead of Mody's reading. The differences between the two editions are relatively minor, however, and are mentioned in the footnotes. The numbers between square brackets in the bhäsya are my own. They correspond to the dandas in Mody's edition. E.g., the number [1.2.3] refers to the third sentence of the commentary on the second sütra of the first chapter of the TA. 
And one says: Grasping either partially or wholly, depending on the understanding from a perspective on objects that are single and many, with reference to meanings of common words, this is to be known as the ordinary commonplace perspective (naigama) (1).

One who knows the perspectives should know that knowledge which is established by the collecting perspective (sangrahanaya) as the one which is expressive of the collective, in general terms, in partial terms, and specific terms (2).

He should know the practical perspective (vyavahära) as broad, established by worldly usage, depending on the ascertainment of 'group, individual, form, existence and name etc.' (3).

He should know concisely the linear perspective (rjusūtranaya) as the kind of grasping having the present as its range; and he should know the verbal perspective (śabdanaya) as the one where word is in accordance with the object, which has qualified stages (4).

Unlike the main body of the text, which is written in prose, this passage consists of four verses in $\bar{a} r y \bar{a}$ metre. It is clearly demarcated by the introductory phrase $\bar{a} h a c a$ and closes with iti, which suggests that we are dealing with a quotation. ${ }^{6}$ Furthermore, the use of vocabulary in these $\bar{a} r y \bar{a}$ differs from the overall style of the bhäsya. For example, the naigama or commonplace perspective is qualified as vyavahärin or 'ordinary' in TABh 1.35.42-43. However, the vyavahära perspective is also discussed as a separate perspective in TABh 1.35.47. This is confusing and does not match the straightforward explanations that characterise most parts of the bhäsya. This strongly suggests that we are dealing with a quotation from an external source.

A similar passage appears later in the commentary on the same sütra in TABh 1.35.90-99:

6 One could argue that we are not necessarily dealing with a quotation from an external source. As mentioned by Gary Tubb and Emery Boose, it is often the mūlakāra who is the subject of a verb in the third person singular such as āha in a commentary (Tubb \& Boose 2007: 227). Likewise, the participle ukta 'may mean "stated by the mülakära"' (idem: 228). Further, even in the case of an auto-commentary, the author 'normally refers to the mülakära as if the mülakära were another person' (idem: 229). Hence, these quotation marks do not necessarily imply that we are dealing with citations from a different work. However, the cited passages do not occur in the TA and, as far as I am aware, they also do not occur in any other text attributed to the author of the TA. It is also unlikely that these verses try to render what is intended by the mülakāra, since in that case there is no reason to write in $\bar{a} r y \bar{a}$ verse while the TA and the TABh are in prose. Hence, the most plausible reading is that we are dealing with genuine quotations from an external source. 
āha ca
[1.35.90] vijñāyaikārthapadāny arthapadāni ca vidhānam ișțạ̣ ca |
[1.35.91] vinyasya parikṣepān nayaih parīksyāṇi tattvāni ||1\|
[1.35.92] jũānaṃ saviparyāsam trayaḥ śrayanty ādito nayāḥ sarvam |
[1.35.93] samyagdrșțer jñānam mithyādrșțer viparyāsaḥ ||2||
[1.35.94] rjusūtraḥ șaț śrayate mateh śrutopagrahād ananyatvāt |
[1.35.95] śrutakevale tu śabdaḥ śrayate nānyac chrutāingatvāt $\|3\|$
[1.35.96] mithyādrștyajñāne na śrayate nāsya kaścid ajño 'sti |
[1.35.97] jñasvābhāvyāj jī̄o mithyādrșțir na cāpy ajñah \|4\|
[1.35.98] iti nayavādāś citrāḥ kvacid viruddhā ivātha ca viśuddhāḥ|
[1.35.99] laukikaviṣayātītās tattvajñānārtham adhigamyāḥ ||5\|

Having understood words of single meaning ${ }^{7}$ and words referring to objects and their appropriate classification, having set them out completely, the entities are to be examined by the perspectives (naya) (1).

The first three perspectives apply to all [types of cognition], i.e., knowledge together with its opposite; knowledge results from right view, delusion results from wrong view (2).

The linear perspective (rjusūtra) applies to six [types of cognition] due to identity, since testimony seizes ordinary cognition; but the literal perspective (śabda) applies to testimony and absolute knowledge [only] because it is dependent on testimony, not on anything else (3).

[The literal perspective] does not apply to wrong view or nonknowledge because there is not any [soul which is] unknowing of that; and there is also no unknowing soul having wrong view, due to the own nature of having knowledge (4).

In this manner, the statements from the different perspectives (naya$v \bar{a} d a$ ) are manifold; first they appear to be opposed ${ }^{8}$ and yet they are free from vice; surpassing the range of the worldly they are to be studied for the sake of knowledge of reality (5).

These five verses are also written in $\bar{a} r y \bar{a}$ metre, and form the very last part of the first chapter. Just as the previous āryā verses, they summarise the discussion of nayavāda. They are introduced in the same way as the first four $\bar{a} r y \bar{a}$, even though the passage is not closed with iti. The omission of iti might be explained by the fact that TABh 1.35 .99 is immediately followed by a standard

7 The meaning of ekārthapadāni is not entirely clear to me. Perhaps it is 'synonyms'.

8 Alternatively, 'in their pure form they appear to be opposed'. 
formula which starts with iti and indicates the end of the chapter. ${ }^{9}$ As such, it is slightly ambiguous whether the particle iti forms the beginning of a new sentence or simply closes the $\bar{a} r y \bar{a}$.

The third apparent quotation appears in the fifth chapter, and consists of just one verse, which deals with the concept of paramānu:

uktạn ca

[5.25.1] kāraṇam eva tad antyam sūkṣmo nityaś ca paramāṇuḥ |

[5.25.2] ekarasagandhavarṇo dvisparśạ̣ kāryalingaś ca || iti |

And it has been said: 'The cause is indeed that, the ultimate (antya). The infinitesimal particle is subtle and eternal. It has one taste, smell and colour, two types of touch and its mark is the effect.'

This verse is introduced with uktam ca instead of äha ca and is composed in upagiti metre. The fact that these three passages in verse seem to be quotations raises the question of their possible source. If the TABh is an auto-commentary, as Suzuko Ohira and M.A. Dhaky claim, then we have to assume that the author cites a Sanskrit source that not only predates the TABh but also predates the TA. ${ }^{10}$ Since the first passage discusses an exclusively Jaina topic, i.e., nayavāda, it has to be derived from a Jaina source. However, the TA is usually seen as the first Jaina text in Sanskrit, and there is no evidence that other Jaina philosophical texts were written in Sanskrit before the TA. ${ }^{11}$ Yet, if the TABh is not an auto-commentary, the source of the quotations could theoretically postdate the TA. But even in that case, it is still not clear which text could have been the source since there are no extant Jaina philosophical texts in Sanskrit that predate the TABh apart from the TA. Regardless, if we are dealing with proper quotations, we have to accept that another philosophical Jaina text in Sanskrit existed before the TABh was finalised. It cannot be completely ruled out that the verses were added by a different writer during the final redaction of the TABh. ${ }^{2}$ However, the fact that the original sources are lost and that other works do not refer to these texts, rather suggests an early date.

iti tattvārthādhigame 'rhatpravacanasangrahe prathamo 'dhyāyah samāptaḥ (TABh 1.35 .100). Similar sentences are used at the end of the other chapters.

$10 \quad$ Ohira 1982, Dhaky 1996.

11 It is also unlikely that the passages are Sanskrit renderings of verses from a Prākrit source. In such a case, it would be strange to present the verses as a quotation.

12 This must have happened before the composition of the țīka (9th cent. CE). 


\section{Other Verses in the TABh}

In order to understand the position of the TA and TABh in the early development of Jaina philosophy, it is relevant to know the source of the different quotations in the TABh, and whether they are derived from a single source. This cannot be answered on the basis of these quotations alone. However, apart from the three explicit quotations, the main body of the TABh has two more passages in verse, which could potentially be copied from the same source as the quotations. The first verse appears in chapter six:

\section{[6.9.18] saṃrambhaḥ sakaṣāyaḥ paritāpanayā bhavet samārambhạ̣| [6.9.19] ārambhạ̣ prāṇivadhaḥ trividho yogas tato jñeyạ̣ \|}

The threefold undertaking (yoga) is therefore to be known as (1) action (samrambha), which is accompanied by passion, (2) undertaking (samārambhah), which may appear by torment (paritāpanā), and (3) violent action (ärambha), which is the slaughter of living beings.

This verse is composed in āryā metre but is not marked as a quotation. Yet, one could question whether this verse was included in the TABh at the time of its composition since Siddhasenagani's tịkā does not comment on it. ${ }^{13}$

The last passage in verse occurs at the end of the final chapter, at TABh 10.7.157-220. This passage consists of 32 verses in anuștubh metre, which were previously analysed and translated by Zydenbos. ${ }^{14}$ These verses summarise the content of the last chapter, which deals with mokșa, and address some additional problems, such as the question of whether a bodiless being can experience happiness. Since these verses provide a summary of the chapter, it is highly unlikely that they were derived from another source. As such, we can assume that these last verses were composed by the author or redactor of the bhāsya, unlike the quotations in the first and fifth chapter.

There is no reason to assume that the different verses in the TABh are derived from a single pre-existent source. First, only three of the five passages are intro-

13 Kapadia prints a slightly different reading, which corresponds with manuscript $C$ in Mody's edition. Mody has one more passage in āryā metre, which occurs in chapter five. However, these āryās are part of a longer passage that Mody presents in brackets, indicating that this part does not belong to the TABh. The whole passage is omitted by Kapadia. Mody's edition mentions a comment found in several manuscripts that identifies this passage as a part of Haribhadra's commentary. Therefore, this passage is omitted in the present analysis.

14 See Zydenbos 1983. For this reason, I have not translated these verses in this article. 
duced as quotations. Second, the verses are composed in different meters. The quotations in the first chapter and the verse in the sixth chapter are in $\bar{a} r y \bar{a}$, the quotation from the fifth chapter is in upagiti, and the last 32 verses of the tenth chapter are in anuștubh. In short, it seems that the TABh contains at least four passages that were derived from various texts that have not been preserved. This shows that the TA and the TABh were not the only Jaina texts in Sanskrit at the time of the final redaction of the TABh.

\section{3 The sambandhakārikās}

Since we do not have any Sanskrit texts from the Jaina tradition that were composed before the TABh apart from the TA, we cannot use the quotations in the TABh to answer with certainty the question whether the TABh was written at a later stage than the TA. However, several manuscripts of the TABh include two additions in verse that are most relevant for the discussion of authorship. ${ }^{15}$ The first part is an introductory section, known as the sambandhakārikās. It consists of 31 verses in $\bar{a} r y \bar{a}$ metre. The second addition is a praśasti, added at the end of the work. It consists of six verses in $\bar{a} r y \bar{a}$ metre and provides information about the work and the author. Both parts can be found in Siddhasenagani's tịk ${ }^{16}{ }^{16}$ The following two sections contain the Sanskrit text and translation of the sam- $k$ and the praśasti, and discuss what the content of these passages can tell us about the authorship of the TA and the TABh.

The sam- $k$ introduce the TABh as follows:

samyagdarśanaśuddhaṃ yo jñānaṃ viratim eva cāpnoti | duhkhanimittam apidam tena sulabdham bhavati janma $\|1\|$ janmani karmakleśair anubaddhe 'smiṇs tathā prayatitaryam |

15 For a discussion of the manuscripts of the TA and the TABh, see Ohira 1982: 1-6.

16 Siddhasenagani does comment on the praśasti, but he does not comment on the sam$k$. However, he includes the commentary of Devagupta on these verses in his own work (Ohira 1982: 25). Devagupta's comments on the sam- $k$ can be found in Kapadia's edition of the țīka . As pointed out by Hans Bakker (personal communication, April 27, 2020), it is possible that the commentator Devagupta is the same Devagupta mentioned as the student of Harigupta in the praśasti of Uddyotanasūri's Kuvalayamālā (Upādhye 1959: 282, Chojnacki 2008, vol. 2, 771). If this is indeed the case, we can date Devagupta's commentary to the first quarter of the 6th cent. $\mathrm{CE}$, which would provide a terminus ad quem for the TABh and the sam-k. For a discussion of Uddyotanasūri's praśasti, see Bakker 2020: 61 and Upādhye 1970: 96-112. 
karmakleśābhāvo yathā bhavaty eșa paramārthaḥ $\|2\|$ paramārthālābhe vā doșeșv ārambhakasvabhāveșu| kuśalānubandham eva syād anavadyam yathā karma $\|3\|$ karmāhitam iha cāmutra cādhamatamo narah samārabhate | iha phalam eva tv adhamo vimadhyamas tūbhayaphalārtham $\|4\|$ paralokahitāyaiva pravartate madhyamaḥ kriyāsu sadā| mokșāyaiva tu ghațate viśiștamatir uttamaḥ puruṣaḥ $\|5\|$ yas tu krtāartho 'py uttamam avāpya dharmam parebhya upadiśati | nityam sa uttamebhyo 'py uttama iti püjyatama eva $\|6\|$ tasmād arhati püjām arhann evottamottamo loke | devarșinarendrebhyah püjyebhyo 'py anyasattvānām $\|7\|$ abhyarcanād arhatāọ manahprasādas tatah samādhiś ca | tasmād api niḥśreyasam ato hi tatpūjanam nyāyyam $\|8\|$ tïrthapravartanaphalam yat proktam karma tïrthakaranāma | tasyodayāt krtārtho 'py arhams tīrtham pravartayati $\|9\|$ tatsvābhāryād eva prakāśayati bhāskaro yathā lokam | tìrthapravartanāya pravartate tìrthakara evam $\|10\|$ yah śubhakarmā sevanabhāvitabhāvo bhaveșv anekeșu| jajñe jñātekșvākuṣu siddhārthanarendrakuladīpạ̣ ||11\| jñānaiḥ pūrvādhigatair apratipatitair matiśrutāvadhibhị̣| tribhir api śuddhair yuktah śaityadyutikāntibhir ivenduh || $12 \|$ subhasārasattvasaṃhananavīryamāhātmyarūpagunayuktah | jagati mahāvīra iti tridaśair gunataḥ krtābhikhyaḥ ||13\| svayam eva buddhatattvah sattvahitābhyudyatācalitasattvaḥ | abhinanditaśubhasattvaḥ sendrair lokāntikair devaih ||14\| janmajarāmaran̄ārttam jagad aśaraṇam abhisamīkṣya niḥsāram | sphìtam apahāya rājyam śamāya dhīmān pravavrāja ||15|| pratipadyāśubhaśamanam niḥśreyasasādhakạ̣ śramaṇalingam | krtasāmāyikakarmā vratāni vidhivat samāropya $\|16\|$ samyaktvajñānacāritrasaṃvaratapahsamādhibalayuktaḥ| mohādīni nihatyāsubhāni catvāri karmāṇi || $17 \|$ kevalam adhigamya vibhuḥ svayam eva jñānadarśanam anantam | lokahitāya krtārtha 'pi deśayām āsa tīrtham idam $\|18\|$ dvividham anekadvādaśavidham mahāvișayam amitagamayuktam | saṃsārārṇavapāragamanāya dụ̂khakșayāyālam ||19|| granthārthavacanapațubhih prayatnavadbhir api vādibhir nipunaị | krtvā trikaraṇaśuddham tasmai paramarșaye namaskāram | pūjyatamāya bhagavate vīrāya vilīnamohāya ||21\| tattvārthädhigamākhyam bahvartham samgraham laghugrantham | vakssyāmi śisyahitam imam arhadvacanaikadeśasya $\|22\|$ 
mahato 'timahāvișayasya durgamagranthabhāssyy' apārasya | kah śaktah pratyāsam jinavacanamahodadheh kartum ||23\| śirasā giriṃ bibhitsed uccikșipsec ca sa kșitiṃ dorbhyām | pratitìrșec ca samudram mitsec ca punaḥ kuśāgrena ||24|| vyomnīndum cikramișen merugiriṃ pānininā cikampayișet | gatyānilam jigịsec caramasamudrạ̣ pipāsec ca $\|25\|$ khadyotakaprabhābhih so 'bhibubhūṣec ca bhāskaram mohāt | yo 'timahāgranthārtham jinavacanam samjigh ṛkșeta $\|26\|$ ekam api tu jinavacanādyasmān nirvāhakam padam bhavati $\mid$ śrūyante cānantāh sāmāyikamātrapadasiddhāḥ $\|_{27 \|}$ tasmāt tatprāmānnyāt samāsato vyāsataś ca jinavacanam | śreya iti nirvicāram grāhyam dhāryaṃ ca vācyaṃ ca $\|28\|$ na bhavati dharmah śrotuh sarvasyaikāntato hitaśravaṇāt | bruvato 'nugrahabuddhyā vaktus tv ekāntato bhavati ||29|| śramam avicintyātmagatam tasmāc śreyah sadopadeștavyam | ātmānam ca param ca hi hitopadeșțānugrhnāti $\| 30 \mid$ na rte ca mokșamārgād dhitopadeśo 'sti jagati krtsne 'smin | tasmāt param imam ${ }^{18}$ eveti mokșamārgam pravakșāmi $\|31\|$ iti sambandhakārikāh samāptāh \|

For him who obtains knowledge, which is pure through right worldview (samyakdarśanaśuddha), ${ }^{19}$ and indeed non-passion (virati), for him there is good birth, even though this is the cause of pain (1).

Pains have to be taken in this birth, which is connected with the afflictions of karman, in such a way that the absence of the afflictions of karman occurs; this is the highest aim (2).

Or, when there is no acquirement of the highest aim, when there are faults, being the inherent nature of someone who performs [violent activities] ${ }^{20}$ (ärambhakasvabhāva), [pains have to be taken] in such a way that karman might be faultless, having indeed a suitable connection (kuśalānubandha) (3).

The very lowest man (adhamatama) undertakes evil deeds here and there (i.e., in the next life). But the low man (adhama) [undertakes deeds

17 For a discussion of the somewhat counter-intuitive word division bhāșy apārasya, see below.

18 Kapadia reads idam.

19 Alternatively, one could interpret the compound as samyagdarśanam śuddham.

20 The term a arambha has a very negative connotation in Jainism, and carries the meaning of violent action (Johnson 1995: 38). 
which give] fruit here only. And the perfectly mediocre ${ }^{21}$ man (vimadhya$m a)$ [undertakes deeds] for the sake of the fruit in both [lives] (ubhayaphalärtha) (4).

The middling man (madhyama) always engages in actions for the sake of the future world only, while the highest man, having excellent cognition is suitable for liberation only (5).

But he who has indeed accomplished his goal, having obtained the highest, teaches the dharma to others. He is always the highest of the very highest. Thus, he is indeed the most venerable (6).

Therefore, the Arhat alone, who is the very highest in this world, is worthy of veneration from gods, sages, and lords, even though they are worthy of veneration from other beings [themselves] (7).

From the worship of the Arhats comes peace of mind (manahprasāda), and from that samādhi. And from that comes ultimate bliss (nihśreyasa). Therefore, worship of them is appropriate (8).

That which is called 'body-determining karman related to the tirtha-

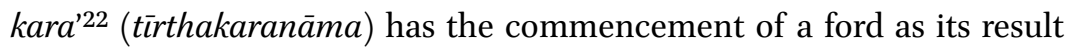
(tirthapravartanaphala). From the occurrence of that, the Arhat, having his goal accomplished, also proceeds to initiate a ford (9).

Just as the sun illuminates the world out of its own nature, in the same way the tìrthakara is occupied with ${ }^{23}$ making a ford (10).

He who is of virtuous conduct ${ }^{24}$ (śubhakarman), whose being is pervaded by serving in many lives, was born in the well-known Ikșvāku [clan], being the lamp of the lineage of kings whose goals are accomplished (11).

... endowed with knowledge, acquired previously, which does not disappear (apratipatita), being ordinary cognition, testimony, and cosmic perception (matiśrutāvadhi), which are all three pure, like the moon, [which is endowed] with coolness, splendour, and brightness, ... (12)

... endowed with auspiciousness, energy, strength, firmness, power, magnanimity, beauty, and virtue, who is made famous as 'Mahāvīra' in this world by the gods because of his virtues, ... (13)

... he himself indeed, whose essence is enlightened, whose strength is unshakable, who is engaged in beneficial [deeds] for [other] beings,

21 The prefix $v i$ - is interpreted as visisița-.

22 This type of karman is listed in TA 8.12.

23 The middle voice fits the sväbhärya character of the activity.

24 Alternatively, 'auspicious karman'. 
whose auspicious essence is venerated by the lokāntika gods, ${ }^{25}$ including Indra, ... (14)

... after having seen the world being without refuge, without essence, afflicted by birth, old age, and death, the wise one renounced the world, for the sake of peace, leaving behind a prosperous kingdom (15).

After taking up the mark of asceticism, which is destroying that which is inauspicous, [and which is] the means to ultimate bliss, [he who is] engaged in the performance of sāmāyika, ${ }^{26}$ after undertaking the vows according to the rules, ... (16)

... endowed with righteousness, knowledge, stopping, ${ }^{27}$ asceticism, samädhi, power, ${ }^{28}$ having destroyed four [types of] inauspicous karman, beginning with deluding $[$ karman $],{ }^{29} \ldots$ (17)

... after having attained absolute knowledge, which is unlimited knowledge and worldview, the lord himself, even though he has accomplished his goals, taught this path (tirtha) ${ }^{30}$ for the benefit of this world, ... (18)

... [i.e.], the twofold, manifold, and twelvefold [varieties of knowledge from testimony], ${ }^{31}$ having great range, endowed with many perspectives ${ }^{32}$ (amitagamayukta), being adequate for the annihilation of pain, in order to go to the other shore of the ocean of samsāra (19).

It cannot be surpassed by other skilful teachers, even [not by those] who are diligent and skilful with respect to the meaning and words of scripture (granthārthavacanapațu), just like the sun [cannot be surpassed] by all lights (20).

After having made homage to that great sage with purity of the three faculties, ${ }^{33}$ [to him who is] a most venerable illustrious hero, whose delusion is gone, ... (21)

..., I will teach this short text, called Tattvārthädhigama-an important (bahvartha) compendium (samgraha) of some ${ }^{34}$ of the words of the Arhat, which is beneficial for students (22).

25 TA 4.25 explains that the lokāntika gods dwell in Brahmaloka (brahmalokālayā lokāntikāh $)$.

$26 \quad$ I.e., the totality of the Jaina path.

27 I.e., of karmic influx (see TA 1.4).

28 Alternatively, 'power acquired by austerities' (tapo[bala]) and 'force of meditation' (samādhibala).

29 This type of karman is listed in TA 10.1.

$30 \quad$ Alternatively, 'showed this ford'.

$3^{1} \quad$ I.e., the canonical Jaina scriptures.

32 The term gama is a synonym of naya. See also Mody 1903: 30, n. 1.

33 I.e., body, speech, and mind. See, e.g., Balcerowicz 2008: 36 .

34 Lit. 'a part'. 
Who, in enunciating a difficult text (durgamagranthabhāṣin), is able to make a summary ${ }^{35}$ (pratyāsa) of the great ocean of the words of the Jina, which is boundless, whose scope is way larger than large? (23)

[He who would desire to comprehend the word of the Jina, which is the subject of a very extensive text $],{ }^{36}$ he could desire to break a mountain with the head, and he could desire to throw up the earth with two arms, and he could desire to cross the ocean, and further, he could desire to measure [the ocean] with the tip of the kuśa grass ... (24)

... and he could desire to move the moon in the sky, and he could desire to shake mount Meru with one hand, and he could desire to move [along with] the wind [by his own] movement ${ }^{37}$ (gatyānila), and he could desire to drink the deepest ocean ... (25)

... and he could desire to surpass the sun with the light of fireflies out of delusion. He who would desire to comprehend (samjighrkșeta) ${ }^{38}$ the word of the Jina, which is the subject of a very extensive text (atimaha $\bar{a}$ granthärtha), [he could desire to ... (see 24-26)] (26)

Because, even though ${ }^{39}$ one state ( $p a d a$ ) which brings about deliverance comes into being ${ }^{40}$ from the word of the Jina, yet, infinitely [many] are heard to have accomplished a state consisting of sāmāyika (27) ...

... therefore, from the authority of that, ${ }^{41}$ the word of the Jina in a brief and extended [form], should be accepted, without doubt, [thinking] "[this is] the best', and it should be remembered, and it should be taught (28).

There is no exclusive ${ }^{42}$ (ekāntatas) dharma for the hearer from the act of hearing which is beneficial for all. However, that final [dharma] (ekāntatas) comes into being [for someone who is] speaking because the mind of the speaker is promoting a good thing ${ }^{43}(29)$.

Therefore, the bliss of final emancipation should always be taught without thinking about the trouble for oneself. Certainly, someone who teaches [that which is] beneficial favours himself as well as the other (30).

35 This is an unusual word. Haribhadra interprets pratyāsa as samgraha (Mody 19o3:30, n. 3).

$36 \quad$ See $s a m-k 26$.

37 I.e., going as fast as the wind.

38 Middle voice, metri causa.

39 Alternatively, 'in fact'.

40 In other words, the highest accomplishing state becomes possible.

41 I.e., because many people have reached the sāmāyika state by the words of the Jina.

42 I.e., focused on one thing.

43 Lit. 'from the mind, [which is] showing favour (anugrahabuddhi), of the speaker (bruvat)'. 
And besides the path to liberation there is no beneficial teaching in this entire world. Therefore, I will teach indeed this very highest path to liberation (31).

Thus, the introductory verses are now completed.

The introductory verses deal with various topics related to Jaina doctrine and the nature of the TA/TABh. The structure of the sam-k can be summarised as follows: ${ }^{4}$

$\begin{array}{lll}\text { i. } & \text { The Jaina ideal } & 1-3 \\ \text { ii. } & \text { Classification of human beings } & 4-6 \\ \text { iii. } & \text { Nature of the Tīrthakara } & 7-10 \\ \text { iv. } & \text { Life of Mahāvīra } & 11-20 \\ \text { v. } & \text { Salutation } & 21 \\ \text { vi. } & \text { Nature of the work } & 22 \\ \text { vii. } & \text { Difficulty of the task of the author } & 23-26 \\ \text { viii. } & \text { Benefits for the author and others } & 27-30 \\ \text { ix. } & \text { Nature of the work } & 31\end{array}$

It is somewhat strange that the salutation is situated in the middle of the composition, and that the verses on the nature of the work are interrupted by verse $23-30$. Ohira speculates that verse 21,22 , and 31 'were originally composed as the benedictory verse' to which the other verses were added. ${ }^{45}$ I will elaborate on this observation later in this section after discussing some peculiar elements that can tell us more about the internal coherence of the introductory verses and their relationship with the TABh.

The opening verse of the sam- $k$ resembles the first sütra of the TA, which runs as follows:

samyagdarśanajñānacāritrāṇi mokșamārgaḥ ||1.1||

The path to liberation [is constituted by] right worldview, [right] knowledge, and [right] conduct.

A similar idea is expressed in the opening verse of the sam- $k$ :

44 The analysis of the different parts follows Ohira 1982: 27-28.

45 Ohira 1982: 27. 
samyagdarśanaśuddhaṃ yo jñānaṃ viratim eva cāpnoti | duḥkhanimittam apīdam tena sulabdhaṃ bhavatijanma $\|1\|$

[For] him who obtains knowledge, which is pure through right worldview, and indeed non-passion, for him there is good birth, even though this is the cause of pain.

Although the opening verse of the sam- $k$ seems to deal with the three standard elements of mokșamārga (i.e., darśana, jñāna, and cāritra), the formulation deviates from TA 1.1. First, knowledge ( jñanna) plays a central role, while right worldview (samyagdarśana) is somehow presented as an aspect in the acquisition of knowledge. This raises the question why the author of the sam- $k$ chooses to deviate from the way in which mokșamärga is presented in TA 1.1. This deviation would be even more peculiar if these introductory verses are composed by the author of the TA and/or TABh. One may wonder whether it is possible that the author of the sam-k consciously modified the idea presented in TA 1.1 to stress the paramount importance of jñana in the quest for liberation in line with the views of other philosophical treatises such as the Nyāyasūtra. ${ }^{46}$ Apart from the unusual relation between jñanna and darśana in sam-k1, it is also remarkable that căritra is not mentioned in the sam- $k$ at all. Of course, one can interpret virati as cāritra since right conduct results from non-passion in the Jaina perspective. Nevertheless, it remains unclear why the author of the sam-k opens the introductory verses with such an unusual summary of mokșamārga.

The sam-k use some words that are not very common for traditional Jaina texts but clearly resonate with Nyayya doctrine. An illustration of this phenomenon can be found in sam- $k$ :

abhyarcanād arhatāị manahprasādas tatah samādhiś ca| tasmād api niḥśreyasam ato hi tatpūjanaṃ nyāyyam $\|8\|$

From the worship of the Arhats comes peace of mind, and from that samādhi. And from that comes ultimate bliss. Therefore, worship of them is appropriate.

46 The order of darśana, jñāna, and cāritra in TA 1.1 does not correspond with most canonical formulations, in which jñāna is usually the first element, followed by darśana (Ohira 1982: 55). Therefore, one could also argue that the author of the sam- $k$ simply favours the traditional formulation. However, this does not explain why cāritra is replaced with virati. 
The term 'ultimate bliss' (nihśreyasa) is uncommon for the Jaina tradition, even though it is presented in this verse as the highest goal. Yet, nihśreyasa plays a crucial role in Nyāya philosophy. ${ }^{47}$ The same term is used in sam- $k 16$, where 'the mark of asceticism' is described as 'the means to ultimate bliss' (nihśreyasasādhakam śramanalingam). The fact that the term nihśreyasa occurs twice in this short introduction to the TABh demonstrates the importance of the concept to the composer of this passage, which indicates that the author was well acquainted with Nyaya thought. Furthermore, this term deviates from the terminology in the TA and TABh, which strongly suggests that the sam-k were written by a different hand..$^{48}$

After the first half of the sam-k, which covers the way to liberation, the suitability of different kinds of people to achieve liberation, and the life of Mahāvira, who reached the highest goal and taught the Jaina doctrine, the text continues with a salutation to Mahāvirra (sam-k21). Then, the author introduces the work as a summary of the words of Mahāvira in verse 22. As mentioned earlier, it is somewhat odd that the salutation starts at sam-k 21, and that the statement about the nature of the work in sam- $k 22$ and 31 is interrupted by verse 23-30. In fact, the structure of the text seems to suggest that the first historical layer consisted of verses 21,22 , and 31 only, which would constitute a proper introduction for the TA: 49

47 The Nyāyasūtra states at its beginning that knowledge of the categories leads to ultimate bless (nihśreyasa). See, e.g., Angot 20og: 246-247.

48 The tenth chapter of the TA deals with liberation $(m o k s a)$. Instead of the term nihśreyasa, which is used in the sam- $k$, this part of the TABh associates mokșa with 'unsurpassed (anuttara) bliss (sukha)'. The 27th verse of the concluding verses of the tenth chapter reads: punyakarmavipākāc ca sukham iștendriyārthajam | karmakleśavimokșāc ca mokșe sukham anuttaram, 'And by the fruition of good karma there is bliss, produced by a desired object of the senses; but by the liberation from the afflictions of karma in mokșa, there is unsurpassed bliss.' Tr. Zydenbos 1983: 37 .

49 Ohira observes some similarities with the introductory verse of the Sarvārthasiddhi, and writes that Pūjyapāda's mañgalācarana 'was directly derived' from sam- $k 21$ and $3_{1}^{1}$ (Ohira 1982: 26-30). Pūjyapāda's introductory verse runs as follows: mokșamārgasya netāram bhettāram karmabhūbṛtām | jñātāram viśvatattvānām vande tadgunalabdhaye, 'I bow to the Lord, the promulgator of the path to liberation, the destroyer of mountains of karmas and the knower of the whole reality, so that I may realize these qualities'. Ed. and tr. Jain 1992: 1. Even though there are some similarities, such as the word mokșamärga in both texts, and jagat in the sam-k and viśva in the Sarvārthasiddhi, it is hard to tell how these two passages relate to each other, and Ohira's idea that Pūjyapāda used sam- $k 21$ and $3_{1}$ for his own opening verse seems rather speculative. Nevertheless, Pūjyapāda's verse shows that a short introduction with a reference to mokșamārga and the Jina was as an appropriate opening for a commentary on the TA. 


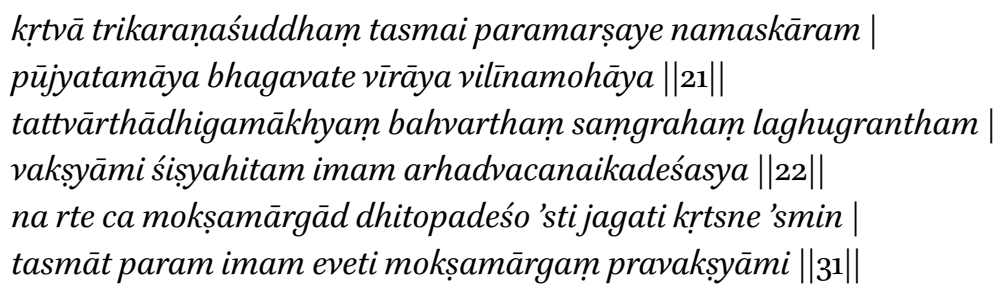

After having made homage to that great sage with purity of the three faculties, [to him who is] a most venerable, illustrious hero, whose delusion is gone (21),

I will teach this short text, called Tattvārthädhigama, an important compendium of some of the words of the Arhat, [which is] beneficial for students (22).

And besides the path to liberation, there is no beneficial teaching in this entire world. Therefore, I will teach indeed this very highest path to liberation (31).

Verse 22 forms the core of the sam-k: it mentions the goal and the title of the work that the sam-k introduce. Even though the work is usually called Tattvārthasūtra or Tattvārthädhigamasūtra, the text is labelled in verse 22 as Tattvārthädhigama, which can be translated as 'A Study of the Categories'. By using the verb vaksyami, the author of the sam-k presents himself as the author of the text that the sam- $k$ introduce. A similar expression is used in the final verse of the sam-k, which ends with the words imam [...] mokșamārgam pravaksyamini, 'I will teach this path to liberation. ${ }^{50}$ However, this does not imply that the sam-k were actually written by the author of the TA or the TABh. Even though most contemporary scholars agree that the TA predates the sam- $k$ and praśasti, there is no consensus about the question whether these verses were written by the author of the bhäsya. ${ }^{51}$

Even though the sam- $k$ mention the title of the work that it introduces, the sam- $k$ use ambiguous terms to characterise this work, making it hard to determine the relation with the bhäsya. The work is presented as a summary or

\footnotetext{
$50 \quad$ sam-k 31.

51 Dhaky claims that the TA, the TABh, the sam-k, and the praśasti are all written by Umāsvāti (Dhaky 1996: 6o). Zydenbos attributes the sam-k and praśasti to the author of the bhāsya but he writes that 'we may safely assume that the Sūtra and the Bhāṣya are not by one and the same author' (Zydenbos 1983: 10, 12). Ohira holds basically the same position as Dhaky even though she mentions that sam-k 21, 22 and 31 were possibly composed first as benedictory verses (Ohira 1982: 26-28).
} 
compendium (samgraha) of Mahāvira's teachings, and the author describes his text as a laghugrantha. Since the TABh is a relatively extensive commentary, it is not an obvious choice to describe the Tattvārthādhigama as a 'short text' if it includes the bhäsya. Yet, one can argue that the author contrasts the teachings of the Arhat with the size of his own text, and wants to say that his text is relatively short compared to the vast amount of Mahāvirra's teachings. Such an interpretation may seem somewhat far-fetched, especially given the straightforward character of the previous verses. However, the next verse seems to go in this direction:

mahato 'timahāvișayasya durgamagranthabhāṣy apārasya | kah śaktah pratyāsam jinavacanamahodadheh kartum ||23||

Who, in enunciating a difficult text, is able to make a summary of the great ocean of the words of the Jina, which is boundless, whose scope is far larger than large?

This verse elaborates on the enormous extent of the words of the Jina and contains some curious elements. First, the text of the author is described as a pratyāsa. This is a highly unusual word. Haribhadra's commentary interprets pratyāsa as samgraha, which is used in sam- $k 22 .{ }^{52}$ But even if we follow this interpretation, it does not help in deciding whether this refers to the text with the commentary. Second, it is very easy to misread the first line of the verse. In any Indian script, the compound durgamagranthabhāsy is not separated from apārasya. It is very likely that a reader of the manuscript will read durgama-grantha-bhāsya-pārasya, especially since manuscripts of the sam-k usually contain the TA accompanied by the bhäsya. In this way, one could assume that the author of the sam-k claims to have written a grantha and a bhäsya, i.e., a root text and a commentary. This would support the view that the bhassya is an auto-commentary. Yet, this reading is problematic syntactically, unlike the less intuitive reading -bhāsy apārasya.

Up to sam-k 22, the text has a logical structure, and the number of verses that are used for the various subtopics corresponds to the relative importance of these topics. However, the passage that deals with the challenge that the author faces in writing a compendium of the words of the Jina, is quite elaborate and is written in a different style. This is clearly visible in sam- $k 24-26$, where the text compares the challenge of the author with some Herculean tasks: 


\begin{abstract}
śirasā giriṃ bibhitsed uccikșipsec ca sa kṣitịn dorbhyām | pratitīrșec ca samudram mitsec ca punạ kuśāgreṇa ||24|| vyomnindum cikramișen merugiriṃ pāninā cikampayiṣet | gatyānilam jigīṣec caramasamudram pipāsec ca $\|_{25} \mid$ khadyotakaprabhābhị so 'bhibubhūṣec ca bhāskaraṃ mohāt | yo 'timahāgranthārtham jinavacanam samjighṛsseta || 26||
\end{abstract}

He [who] would desire to comprehend the word of the Jina, [which is] the subject of a very extensive text $(26 \mathrm{~cd})$,

he could desire to break a mountain with the head, and he could desire to throw up the earth with two arms (24 ab).

And he could desire to cross the ocean, and further, he could desire to measure [the ocean] with the tip of a piece of kuśa grass (24 cd).

He could desire to move the moon in the sky, [and] he could desire to shake Mount Meru with one hand ( $25 \mathrm{ab}$ ).

He could desire to move [along with] the wind [by his own] movement, and he could desire to drink the deepest ocean $(25 \mathrm{~cd})$.

And he could desire to surpass the sun with the light of fireflies out of delusion $(26 \mathrm{ab})$.

The use of multiple desideratives does not match the style of the previous part and does not appear in the TA or TABh. This can be taken as an argument that the sam- $k$ were not written by the author of the TA or TABh, and we can even question whether this passage was written by the same hand that wrote the first part of the sam-k.

Apart from the difference in style and the unusual length of this passage, it also seems to contradict sam- $k 22$. While sam- $k 22$ states that the author wrote a short text, sam- $k 26$ states that the word of the Jina is the subject of a very extensive text (atimahägranthārtha). Two verses later, there is another ambiguous reference to the size of the work. In sam- $k 28$, the author mentions 'the word of the Jina in a brief and extended form' (samāsato vyāsataś cajinavacanam). It is not clear from the context what this means exactly, but one could interpret it as a reference to the short sütra and extended bhäsya. Yet, why does the author not make more explicit what he means?

Even though there is not enough evidence to rule out the possibility that the sam- $k$ were written by a single hand, it seems more likely that there were at least two different authors. It is hard to explain the difference in style of verses 24-26 if the whole text was composed by one person, and the incoherent statements about the text that the sam-k introduce support the view that we are dealing 
with different historical layers. This would also explain the strange structure of the introduction. ${ }^{53}$

However, what could have been the reason for a later author to expand the original introductory verses? As discussed by Dhaky, the Jaina traditions in the North and the South had different ideas about the authorship of the TA and the TABh, and the Jainas in the South did not transmit the TABh. ${ }^{54}$ Up to the present day, the Digambara tradition does not accept the TABh as an authoritative commentary, and they disagree with the Śvetāmbara Jains who assume that Umāsvāti wrote the TA and the TABh. It is hard to believe that the TA and the TABh were originally composed together and that the Jainas in the South embraced the sütra and rejected the bhäsya. If these texts were written together and contained some elements that were unacceptable to the Jaina community, one would expect that the whole text would be considered heretical. Therefore, it is much more likely that the TABh was written at a later stage, and that the text was received differently in the North and the South.

The dispute about the authority of the TABh might have been a reason for the Jainas in the North to expand the introductory verses of the TA. If the author of the verses that were added to sam- $k 21,22$ and $3^{1}$ indeed tried to legitimate the TABh, it makes perfect sense that he used some ambiguous terms to suggest that the author of the introductory verses claims to be the author of the sütra and the bhäsya. It is clear that this strategy did not influence the views of the Jainas in the South since the TABh never acquired an authoritative position in

53 Unfortunately, apart from the differences in the content and style of some of the verses in the sam-k, there is not much more evidence to reconstruct the history of this text. The metre of the $\bar{a} r y \bar{a}$ s of the $s a m-k$, the TABh, and the praśasti is fairly regular and does not provide further evidence to distinguish the writings of different authors. While the sam- $k$ have only one vipula āryā in sam-k23, almost half of the verses of the praśasti are in vipulā $\bar{a} r y \bar{a}$ (i.e., praśasti 2, 3, and 5). However, this difference can be explained by the fact that the praśasti contains many names, which are harder to fit in a metrical scheme.

In his analysis of the sam- $k$, Balcerowicz writes that 'the style of the sam-k resembles that of the Bhāssya', and that 'there are some stylistic devices in the kārikās typical of the prose style of the Bhāsya, e.g. the frequent use of gerundives (e.g. $k \bar{a}[r i k \bar{a}] s 8,15,28$, etc.) or ablatives of mode that describe their manner of teaching (e.g. samāsato vyāsataś ca in $k \bar{a} 28$, that are evocative of such phrases as purastāl lakșaṇato vidhānataś ca vistarena common to the Bhäsya, e.g. TBh 1.1)' (Balcerowicz 2008: 35). However, these similarities in style do not necessarily imply that these passages were written by the same author, and even if we accept that some of the verses of the sam-k were written by the author of the $b h a \bar{s} y a$, we cannot rule out that some parts of the sam-k were written by a different author.

Some of the manuscripts that were surveyed by Ohira only contain sam $-k 1-9$ and omit the rest (Ohira 1982: 2-3), but it is unclear to me how these verses can form an independent and meaningful introduction to the text. 
the Digambara community. Nevertheless, it gave the northern tradition textual evidence to attribute the TABh to the author of the TA.

\section{$4 \quad$ The praśasti}

The colophon of the TABh, known as the praśasti, is the first source that attributes the TA and the TABh to Umāsvāti and runs as follows:

vācakamukhyasya śivaśriyaḥ prakāśayaśasaḥ praśisyeṇa|

śișyeṇa ghoșanandikșamanasyaikādaśāngavidah $\|1\|$

vācanayā ca mahāvācakakșamaṇamuṇ̣̂apādaśisyasya |

śisyeṇa vācakācāryamūlanāmnah prathitakìrteh $\|2\|$

nyagrodhikāprasūtena viharatā puravare kusumanāmni |

kaubhīsaṇinā svātitanayena vātsīsutenārghyam $\left\|_{3}\right\|$ arhadvacanam samyaggurukrameñāgatam samupadhārya |

duhkhārtam ca durāgamavihatamatịn lokamavalokya ||4|| idam uccairnāgaravācakena sattvānukampayā drbdham | tattvārthādhigamākhyam spaștam umāsvātinā śāstram $\|5\|$ yas tattvādhigamākhyam jñāsyati ca karisyate ca tatroktam | so 'vyābādhasukhākhyam prāpsyaty acireña paramārtham $\|6\|$

[This compendium was composed ${ }^{55}$ by the pupil of the pupil of Śivaśrī, whose fame is widely known, who is the best among the vācakas; by the pupil of kșamana Ghoșanandin, knower of the eleven main scriptural texts $^{56}$ (ekādaśäninavid) (1);

and based on the interpretation ${ }^{57}(v \bar{a} c a n \bar{a})$ of the pupil of mahāvācaka kșamaṇa Muṇụapāda, ${ }^{58}$ by the pupil of vācaka ācārya Mūla, whose fame is known (2),

who was born in Nyagrodhikā, who was spending time in the chief town called Kusuma, ${ }^{59}$ belonging to the Kaubhișani [-gotra], the son of Svāti and Vātsī (3);60

\footnotetext{
$55 \quad$ See praśasti 5.

56 I.e., eleven out of the twelve 'inner limbs' or angas (TA 1.20).

57 Lit. 'by the lesson/recitation'.

$5^{8}$ The names Mūla and Muṇạapāda (lit. the venerable baldhead) are unusual for Jaina ascetics.

59 I.e., Pāțaliputra.

6o It seems that arghyam has to be taken with the next verse. This is exceptional and does not occur in the other verses of the praśasti and sam-k.
} 
after having reflected on the priceless (arghya) ${ }^{61}$ word of the Arhat, which arrived through the succession of right teachers, ${ }^{62}$ after having seen the people whose mind is impeded by wicked teachings ${ }^{63}$ and who are afflicted by pain (4),

this compendium called Tattvārthädhigama was composed $(d r b d h a)^{64}$ in an intelligible way (spașta) out of compassion for the living beings by vācaka Umāsvāti of the uccairnāgara [śākhā $]^{65}(5)$.

He who will know [this compendium] called Tattvādhigama and also does what is said therein, he will soon attain the highest goal, which is also called unimpeded happiness (6).

As mentioned above, it is unclear who the author of these six verses is and how they relate to the sam- $k$. The work to which the praśasti is attached is referred to as a śästra, called the Tattvārthādhigama. ${ }^{66}$ This corresponds with the title mentioned in sam-k 22, even though the sam-k refer to the text as a samgraha (sam-k 22), or pratyāsa (sam-k 23) instead of śāstra. ${ }^{67}$ Praśasti 6 mentions the title Tattvādhigama instead of Tattvārthādhigama. The praśasti attributes the Tattv (ārth) ädhigama to vācaka Umāsvāti. ${ }^{68}$ The name Umāsvāti seems to indicate a Brahmanical background. This would also explain why praśasti 3 mentions Umāsvāti's gotra.$^{69}$ It is hard to locate Nyagrodhikā, which is mentioned as the place of birth of Umāsvāti in praśasti 3, since it could refer to any place which has banyan trees. The same verse also mentions that Umāsvāti spent some time in Kusumapura, another name for Pāțaliputra. ${ }^{70}$

61 The word arghya appears in verse 3 .

62 In other words, the teachings of the Arhat were passed down by the succession of teachers.

63 Alternatively, 'whose ordinary cognition (mati) is hindered (vihata) by the difficult verbal testimonies (durāgama)'.

64 Unlike samdrbdha, drbdha is not a common word.

65 Translation based on Dhaky 1996: 6o. Zydenbos mistranslates 'the lofty nāgaravācaka Umāsvāti' (Zydenbos 1983: 38).

66 Praśasti 5.

67 sam- $k 22$ and praśasti 5 both use the phrase tattvārthādhigamākhya.

68 Praśasti 5.

69 Praśasti 3 mentions that Umāsvāti belonged to the Kaubhīṣani gotra. The first verse of the praśasti specifies Umāsvāti's dīkșāgurukrama (Śivaśrī and Ghoṣanandin), the second verse his vācakācāryakrama or lineage of śikṣāgurus (Muṇ̣apāda and Mūla), and the third verse his parents (Svāti and Vātsī). As noted by Hans Bakker (personal communication, April 23, 2020), this threefold specification also occurs in other Jaina sources, such as the praśasti in Uddyotanasūri's Kuvalayamālā (see Upādhye 1959: 282-283 and Upādhye 1970: 97).

70 Ohira suggests that the author of the praśasti preferred the name Kusuma for metrical reasons (Ohira 1982: 53). 
However, the information in the praśasti should not be taken at face value for several reasons. To begin with, the name Umāsvāti does not appear in any other text that is attributed to him, and the southern tradition did not even attribute the TA to him. ${ }^{71}$ Apart from the praśasti and the later textual tradition, there is no evidence that there was an actual writer with the name Umāsvāti, working in Pātaliputra. Further, the names of the teachers in Umāsvāti's lineage mentioned in praśasti 2, Muṇ̣apāda and Mūla, are quite odd and do not appear in other lineages that mention Umāsvāti. ${ }^{72}$ Given the lack of external evidence that supports the information in the praśasti it is hard to evaluate the veracity of the praśasti. Since it seems that the extended version of the sam-k was written in an attempt to legitimise the TABh as an auto-commentary, one can easily imagine that the praśasti was added to substantiate this idea, and to attribute both texts to Umāsvāti.

\section{5}

\section{Conclusion}

The various verses in the TABh raise some important questions about the position of the TA and the TABh in the early development of Jaina philosophy. Even though it cannot be ruled out that some of the verses were added after the composition of the TABh, it is plausible that they were included in the TABh by the main composer of the TABh. The fact that the tịka does not question the authenticity of these passages and assumes that they were written by the composer of the TABh suggests that the original works from which the quotations were derived were already lost and forgotten when the țīka was composed. My analysis of the different passages in verse shows that it is unlikely that they were derived from a single source and there is no reason to connect them with

71 Ohira 1982: 43. For a discussion of the TA in the southern tradition, see Dhaky 1996.

72 Based on an analysis of the lineages that are mentioned in other texts, Ohira concludes that the praśasti is 'the authentic record of Umāsvāti' (Ohira 1982: 53). However, her analysis does not provide the evidence needed for this conclusion. The lineages in other texts talk about Svāti instead of Umāsvāti and they assign him to the Hārita gotra instead of the Kaubhișani gotra, which is mentioned in praśasti 3 . Furthermore, the teachers that are mentioned in the praśasti do not appear in these lineages. For an overview of the lineages that mention Svāti, see Ohira 1982: 44ff. The fact that the lineages in the praśasti have little in common with other works does not necessarily imply that they have no historical basis. In fact, one could argue that the praśasti has a high degree of authenticity precisely because of its unique character (Hans Bakker, personal communication, April 23, 2020). However, without external sources that confirm the information provided in the praśasti, the veracity of its content remains a matter of speculation. 
the introductory verses and the colophon. These two additions to the TABh are most likely from a later date. The structure of the sam-kindicates that they were written at different stages, and their content suggests that the authorship of the TABh was already a matter of debate when these verses were composed.

\section{References}

Angot, Michel. Le Nyāya-Sūtra de Gautama Akșapāda, le Nyāya-Bhāsya d'Akșapāda Pakṣilasvāmin: l'art de conduire la pensée en Inde ancienne. Indika 2. Paris: Les Belles Lettres, 2009 .

Bakker, Hans T. The Alkhan: A Hunnic People in South Asia. Groningen: Barkhuis, 2020.

Balcerowicz, Piotr. "Some Remarks on the Opening Sections in Jaina Epistemological Treatises." In Śāstrārambha: Inquiries into the Preamble in Sanskrit, edited by Walter Slaje, 25-81. Wiesbaden: Harrassowitz Verlag, 2008.

Boer, Lucas den. "Early Jaina Epistemology: A Study of the Philosophical Chapters of the Tattvārthādhigama. With an English Translation of the Tattvārthādhigamabhāssya I, II.8-25, and v." PhD diss., Leiden University, 2020.

Bronkhorst, Johannes. "On the Chronology of the Tattvärthasūtra and Some Early Commentaries." Wiener Zeitschrift für die Kunde Südasiens 29 (1985): 155-184.

Bronkhorst, Johannes. "Reflections on the History of Jainism." Paper presented at the International Conference on Jainism Through the Ages: An Historical Perspective, Mysore, October 2010.

Chojnacki, Christine. Kuvalayamālā. Roman jaina de 779 composé par Uddyotanasūri. Vol. 1 Étude, Vol. 2 Traduction et annotations. Marburg: Indica et Tibeteca Verlag, 2008.

Dhaky, M.A. "Umāsvāti in Epigraphical and Literary Tradition." Jain Journal 31, no. 2 (1996): 47-65.

Jain, S.A. Reality: English Translation of Pujyapada's Sarvarthasiddhi. Madras: Jwalamalini Trust, 1992.

Johnson, W.J. Harmless Souls: Karmic Bondage and Religious Change in Early Jainism with Special Reference to Umāsvāti and Kundakunda. Lala S.L. Jain Research Series 9. Delhi: Motilal Banarsidass, 1995.

Kapadia, Hiralal Rasikdas. Tattvārthādhigamasūtra, vol. ı. Sheth Devchand Lalbhai Jain Pustakoddhar Fund Series 67. Bombay: Jivanchand Sakerchand Javeri, 1926.

Kapadia, Hiralal Rasikdas. Tattvārthädhigamasūtra, vol. 2. Sheth Devchand Lalbhai Jain Pustakoddhar Fund Series 76. Bombay: Jivanchand Sakerchand Javeri, 1930.

Mody, K.P. Tattvārthādhigamasūtram. Bibliotheca Indica 159. Calcutta: Baptist Mission Press, 1903. 
Ohira, Suzuko. A Study of Tattvārthasūtra with Bhāssya with Special Reference to Authorship and Date. L.D. Series 86. Ahmedabad: L.D. Institute of Indology, 1982.

Tubb, Gary A. and Emery R. Boose. Scholastic Sanskrit. A Manual for Students. Treasury of the Indic Sciences. New York: The American Institute of Buddhist Studies at Columbia University in the City of New York, 2007.

Upādhye, Ā.N. Uddyotana-sūri's Kuvalayamālā: A Unique Campū in Prākrit; Critically edited from rare Mss. material for the first time with an introduction, various readings, notes etc. Part I. Bombay: Bhāratīya Vidyā Bhavana, 1959.

Upādhye, Ā.N. Uddyotana-sūri's Kuvalayamālā: A Unique Campū in Prākrit; Critically edited from rare Mss. material for the first time with various readings etc. Part II. Bombay: Bhāratīya Vidyā Bhavana.

Williams, R. Jaina Yoga: A Surveyof the Mediaeval Śrāvakācāras. London Oriental Series 14. London: Oxford University Press, 1963.

Zydenbos, Robert J. Mokșa in Jainism, according to Umāsvāti. Beiträge zur Südasienforschung 83. Wiesbaden: Franz Steiner Verlag, 1983. 